\title{
Aplikasi Probiotik Untuk Ternak Itik
}

\section{The Aplication of Probiotic on Duck}

\author{
Zurmiati, M. E. Mahata, M. H. Abbas, Wizna \\ Fakultas Peternakan Universitas Andalas \\ Kampus Unand Limau Manis Padang \\ e-mail: zurmiatizahyuja@yahoo.com \\ (Diterima:27 Februari 2014, Disetujui:30 Mei 2014)
}

\begin{abstract}
ABSTRAK
Salah satu usaha untuk meningkatkan efisiensi penggunaan pakan atau menurunkan Feed Convertion Ratio (FCR) dan memperbaiki penampilan produksi ternak unggas antara lain dengan menambahkan berbagai imbuhan pakan seperti enzim dan antibiotik. Saat ini penggunaan antibiotik dalam ransum ternak telah dibatasi karena residunya memberikan efek samping terhadap konsumen, sehingga dicari feed additif lain yang aman seperti probiotik. Probiotik dapat merubah ekosistem mikroba pencernaan selain itu juga menghasilkan antibiotik alami, sehingga berpengaruh terhadap kesehatan dan kinerja inang. Penggunaan probiotik sudah banyak diterapkan untuk ayam, namun pada ternak itik masih sedikit. Penelitian dan penggunaan probiotik sebagai pakan imbuhan masih perlu ditingkatkan agar diperoleh teknik produksi yang efisien dan praktis dan dapat diaplikasikan sehingga mampu memberikan dampak ekonomis terhadap industri peternakan. Probiotik memberikan pengaruh yang baik terhadap itik diantaranya meningkatkan kesehatan dan menurunkan rasio konversi ransum.
\end{abstract}

Kata kunci : probiotik, itik, imbuhan, peternakan

\section{ABSTRACT}

One attempt to improve the efficiency of feed utilization or lower Feed Conversion Ratio (FCR) and improve the performance of poultry production, among others by adding various feed additives like enzymes and antibiotics. Currently the use of antibiotics in animal feed has been limited because the residue give side effects to the consumer, so that searched another safe feed additives such as probiotics. Probiotic can modulate the ecosystems of intestinal microflora besides also produces a natural antibiotic, that is potential to effect the health and performance of host. Probiotic have been widely used on chicken, however on duck still little. The research dealing with probiotic as additive is necessary to be improved to obtain the efficient and practical production method, which can be implemented to give an economic impact on livestock industry. Probiotic provided a good influence on the ducks including to improve health and reduce feed convertion ratio.

Keywords : probiotic, duck, additive, livestock

\section{PENDAHULUAN}

Peningkatan kesejahteraan dan pendapatan masyarakat yang diikuti dengan kesadaran akan gizi menyebabkan permintaan produk hewani menjadi tinggi, hal ini dapat dilihat dari Konsumsi Nasional protein pada tahun 2011 mencapai 6,14 g/kapita/hari, meningkat $1,99 \%$ dibandingkan pada tahun 2010 yaitu 6,03 g/kapita/hari (Direktorat Jendral Peternakan dan Kesehatan Hewan, 2012). Daging dan telur yang berasal dari unggas diperkirakan dapat menyumbangkan 20-30\% dari total protein produk hewani di negara sedang berkembang (FAO, 2004). Untuk memenuhi kebutuhan protein yang 
mudah dan cepat, maka ternak unggas merupakan pilihan yang tepat, karena selain cepat menghasilkan daging juga menghasilkan telur. Salah satu jenis usaha peternakan unggas yang berpotensi untuk dikembangkan adalah peternakan itik. Kelebihan ternak itik ini adalah lebih tahan terhadap penyakit dibandingkan dengan ayam ras, sehingga pemeliharaannya mudah dan tidak banyak mengandung resiko.

Usaha peternakan itik di Indonesia telah lama dikenal masyarakat. Agar usaha ini dapat memberikan keuntungan yang optimal terutama pemeliharaan secara intensif atau semi intensif bagi pemiliknya maka perlu diperhatikan beberapa hal yang menyangkut manajemen pemeliharaan ternak itik, seperti bibit, pakan dan lingkungan yang mendukung. Pakan merupakan salah satu aspek yang sangat penting dalam produksi ternak oleh karena itu penyediaannya sangat menentukan keberhasilan suatu usaha peternakan. Semakin tinggi konversi ransum akan diiringi dengan peningkatan biaya produksi selama pemeliharaan. Prasetyo (2010) menyatakan rata-rata konversi itik umur 6 minggu berkisar antara 4,13-4,31. Tingginya konversi ransum itik membuat biaya produksi semakin tinggi sehingga peternak tidak sanggup memelihara secara intensif. Ketersediaan pakan dalam jumlah yang cukup, memiliki kontinuitas, berkualitas tinggi dan harga yang relatif murah serta tidak bersaing dengan kebutuhan manusia merupakan syarat yang harus dipenuhi oleh bahan yang akan dijadikan pakan, namun kendala yang sering dialami oleh peternak adalah belum tercukupinya kebutuhan pakan ternak. Sudah umum diketahui bahwa dalam usaha ternak unggas modern, biaya pakan dapat mencapai $70 \%$ dari biaya produksi, lagi pula harga ransum di Indonesia termasuk mahal karena sebagian besar bahan bakunya masih impor.

Berkaitan dengan hal tersebut maka perlu dilakukan terobosan-terobosan dalam bidang teknologi peternakan terutama teknologi yang berkaitan dengan persoalan ransum, sehingga ransum yang diberikan pada ternak lebih efisien. Salah satu cara yang dapat digunakan untuk meningkatkan efisiensi penggunaan pakan Feed Conversion Ratio (FCR) antara lain dengan menambahkan berbagai imbuhan pakan seperti enzim dan antibiotik. Sampai saat ini mekanisme kerja Antibiotic Growth Promoter (AGP) belum diketahui dengan jelas. Diperkirakan penekanan populasi mikroba patogen dalam usus merupakan salah satu cara AGP dalam memacu pertumbuhan atau produksi. AGP juga ikut terserap dengan nutrient serta tertimbun pada daging, telur dan susu, sehingga secara tidak langsung konsumen juga mendapatkan antibiotik dalam jumlah yang rendah. Para ahli kesehatan masyarakat memperkirakan penggunaan antibiotik pada level sub-therapeutic sebagai AGP, kemungkinan besar merupakan penyebab berkembangnya populasi bakteri yang resisten terhadap suatu antibiotik (Kompiang, 2009). Tahun 1969 dilaporkan dampak akibat penggunaan antibiotik dalam pakan yaitu dapat menyebabkan resistensi bakteri pada manusia dan hewan, terutama jika kandungan residunya dalam produk ternak tinggi. Sampai saat ini ransum ternak umumnya masih mengandung antibiotik, akan tetapi dengan alasan masalah resistensi, mulai 1 Januari 2006 Uni Eropa memutuskan untuk melarang penggunaan antibiotik sebagai pakan imbuhan (Simon, 2005).

Dampak negatif yang ada pada penggunaan AGP, mendorong peneliti menganjurkan untuk melarang penggunaannya sebagai feed additif untuk ternak. Upaya mencari penggantinya difokuskan pada bahanbahan alami, seperti mikroba maupun hasil metabolitnya berupa asam-asam organik. Penggunaan bahan-bahan alami diharapkan dapat menurunkan atau meniadakan dampak negatif tanpa menurunkan produktivitas ternak. Kelompok mikroorganisme yang menguntungkan tersebut diberi nama probiotik (Kompiang, 2009).

Populasi mikroorganisme yang ada di dalam saluran pencernaan ada dua macam, yaitu bakteri yang berkoloni di dalam saluran pencernaan itu sendiri (autochonous) (Gusils et al., 1999) dan bakteri yang berasal dari luar 
tubuh ternak dan hidup di dalam saluran pencernaan (allocthonous). Kelompok bakteri yang kedua ini biasanya ditambahkan ke dalam ransum atau air minum ternak sebagai imbuhan pakan (Feed Additive) (Patterson dan Burkholder, 2003). Ahli makanan ternak memberikan istilah pada mikroba yang dijadikan imbuhan pakan tersebut sebagai probiotik. Beberapa data hasil penelitian menunjukan, bahwa bakteri probiotik yang ditambahkan ke dalam ransum atau air minum ternak dapat mencegah infeksi dan kolonisasi patogen di dalam saluran pencernaan ternak (Hidayat, 2010) .

Probiotik merupakan suatu produk yang mengandung mikroba hidup non patogen yang diberikan kepada ternak untuk memperbaiki laju pertumbuhan, efisiensi konversi ransum dan kesehatan ternak (Stark dan Wilkinson, 1989). Fungsi probiotik selain meningkatkan efisiensi ransum, produksi telur, dan menurunkan kadar kolesterol telur serta kolesterol serum, ternyata probiotik juga mampu menurunkan nitrogen non protein dalam darah, konsentrasi asam urat, amonia dan urea dalam darah (Isshiki, 1979).

Tidak semua bakteri dapat dijadikan sebagai probiotik, kecuali bakteri yang dapat memenuhi kriteria tertentu. Syarat bakteri sebagai probiotik adalah bakteri tersebut tidak patogen, aman dikonsumsi, mampu bertahan hidup dan stabil dalam penyimpanan, dapat bertahan hidup dalam saluran pencernaan setelah melewati lambung, dengan kata lain probiotik haruslah tahan terhadap asam dan garam-garam empedu. Review ini akan membahas aplikasi probiotik untuk ternak itik.

\section{PROBIOTIK}

Secara umum probiotik didefinisikan sebagai mikroba hidup yang digunakan sebagai pakan imbuhan dan dapat menguntungkan inangnya dengan meningkatkan keseimbangan mikrobial pencernaannya (Fuller, 1989). Beberapa probiotik diketahui dapat menghasilkan enzim pencernaan seperti amilase, protease dan lipase yang dapat meningkatkan konsentrasi enzim pencernaan pada saluran pencernaan inang sehingga dapat meningkatkan perombakan nutrien. Satu dari alasan penggunaan probiotik yaitu untuk menstabilkan mikroflora pencernaan dan berkompetisi dengan bakteri patogen, dengan demikian strain probiotik harus mencapai usus dalam keadaan hidup dalam jumlah yang cukup. Secara umum, ada beberapa karakteristik dan kriteria keamanan yang harus dimiliki oleh probiotik.

Karakteristik dan kriteria yang aman dari probiotik (Gaggia et al., 2010) :

1. Nontoksik dan nonpatogenik

2. Mempunyai identifikasi taksonomi yang jelas

3. Dapat hidup dalam spesies target

4. Dapat bertahan, berkolonisasi dan bermetabolisme secara aktif dalam target yang ditunjukkan dengan:

a. Tahan terhadap cairan pencernaan dan empedu

b. Persisten dalam saluran pencernaan

c. Menempel pada ephitelium atau mucus

d. Berkompetisi dengan mikroflora inang

5. Memproduksi senyawa antimikrobial

6. Antagonis terhadap patogen

7. Dapat merubah respon imun

8. Tidak berubah dan stabil pada waktu proses penyimpanan dan lapangan

9. Bertahan hidup pada populasi yang tinggi

10. Mempunyai sifat organoleptik yang baik

Bakteri yang umum digunakan sebagai probiotik yaitu Lactobacillus dan Bifidobacteria, kedua jenis bakteri ini dapat mempengaruhi peningkatan kesehatan karena dapat menstimulasi respon imun dan menghambat patogen. Satu faktor kunci dalam seleksi starter probiotik yang baik yaitu kemampuannya untuk bertahan dalam lingkungan asam pada produk akhir fermentasi secara invitro dan kondisi buruk dalam saluran pencernaan atau in vivo. Ketahanan probiotik pada kondisi in vitro dapat dipengaruhi oleh pembentukan metabolit oleh starter seperti asam laktat, asam asetat, hidrogen peroksida dan bakteriosin (Saarela et al., 2000). Berbagai jenis mikroorganisme yang digunakan sebagai probiotik diisolasi dari isi usus pencernaan, mulut, dan kotoran ternak. Pada saat ini, mikroorganisme yang banyak diguna- 
kan sebagai probiotik yaitu strain Lactobacillus, Bifidobacterium, Bacillus spp, Streptococcus, yeast dan Saccharomyces cereviceae. Mikroorganisme tersebut harus non-patogen, gram positif, strain yang spesifik, anti $E$. coli, tahan terhadap cairan empedu, hidup, melekat pada mukosa usus, dan minimal mengandung $30 \times 10^{9} \mathrm{CFU} / \mathrm{g}$ (Pal et al., 2006; Salminen et al., 1996).

Penelitian tentang probiotik telah difokuskan pada pembuktian dalam aspek keamanan dan kemanjuran strain yang terseleksi. Strategi penelitian untuk pembuktian kemanjuran meliputi pengaruh terhadap imunitas, studi anti-infeksi, percobaan secara klinis, kolonisasi dan perjalanannya sepanjang usus pencernaan, sedangkan untuk pembuktian keamanannya yaitu melalui karakterisasi toksisitas dengan mengukur pengaruhnya terhadap status kesehatan, konsumsi pakan dan morfologi mukosa pencernaan. Produk probiotik yang diberikan biasanya distandarisasi berdasarkan perkiraan jumlah kultur dapat hidup (viable), jadi kemampuan strain untuk mencapai populasi sel yang tinggi merupakan hal yang sangat penting.

Salah satu teknologi penggunaan probiotik yang mempunyai sifat Competitive Exclusion (CE), yaitu meliputi pemberian kultur bakteri nonpatogen ke dalam saluran usus ternak untuk menurunkan kolonisasi atau mengurangi populasi bakteri patogen dalam saluran pencernaan (Fuller, 1989; Nurmi et al., 1992; Steer et al., 2000). Pemberian probiotik biasanya dilakukan secara terus menerus, sedangkan pemberian probiotik yang bersifat CE cenderung hanya sekali walaupun penambahan dosis pada umur ternak selanjutnya kemungkinan bermanfaat (Bilgili, 1995). Kultur CE dapat merupakan satu strain yang spesifik atau terdiri dari beberapa strain atau beberapa spesies bakteri, tergantung dari tahap produksi, target dari CE yaitu dapat mengeluarkan patogen dari pencernaan ternak baru lahir atau menggantikan populasi bakteri patogen yang telah terdapat dalam saluran pencernaan. Aplikasi CE yang telah banyak dilakukan diantaranya pemberian campuran bakteri dari ayam dewasa yang sehat untuk ayam baru menetas dan akan memberikan pengaruh anti-Salmonella (Nurmi et al., 1992). Studi terbaru menunjukkan CE efektif dalam menurunkan kolonisasi Salmonella pada anak ayam menyebabkan berkembangnya produksi kultur campuran CE secara komersial di Amerika Serikat (Nisbet et al., 1993; 1996). Kultur campuran akan menurunkan kolonisasi patogen pada dinding usus, sehingga menurunkan jumlah toksin yang dihasilkan. Penggunaan CE Pada ayam petelur, penambahan $B$. substillis menghasilkan penurunan jumlah telur yang cacat dan peningkatan laju bertelur secara signifikan.

\section{MEKANISME KERJA PROBIOTIK}

Probiotik merupakan pakan imbuhan berupa mikroorganisme dapat hidup disaluran pencernaan, bersimbiosis dengan mikroorganisme yang ada, bersifat menguntungkan, dapat meningkatkan pertumbuhan dan efisiensi pakan, serta menyeimbangkan populasi mikroba pada saluran pencernaan, mengendalikan mikroorganisme patogen pada tubuh inang (Fuller, 1992). Menurut Fuller (2002), keseimbangan mikroba usus akan tercapai apabila mikroba yang menguntungkan dapat menekan mikroba yang merugikan, dimana mikroba patogen yang merugikan didesak keluar dari ekosistim saluran pencernaan oleh mikroba normal saluran pencernaan atau mikroba yang menguntungkan. Keuntungan probiotik adalah mencegah reaksi bakteri patogen, merangsang aktivitas peristaltik usus detoksikasi beberapa komponen makanan yang merugikan dan mengeluarkannya, mensuplai enzim untuk membantu mencerna beberapa bahan makanan (Ray, 1996).

Mekanisme kerja probiotik dijelaskan oleh Soeharsono (1998) menyatakan bahwa probiotik merupakan mikroba hidup yang apatogen, yang mekanisme kerjanya mendesak mikroba non-indigenous keluar dari ekosistem saluran pencernaan, dan menggantikan lokasi mikroba pathogen di dalam saluran pencernaan, karena probiotik berasal dari mikroba 
indigenous, maka proses translokasi yang terjadi berjalan secara alamiah di dalam ekosistem usus. Mikroba pathogen nonindegenous merupakan benda asing, oleh karena itu didesak keluar dari saluran pencernaan. Sementara Klaim (2006) mengungkapkan bahwa probiotik juga ikut berperan dalam meningkatkan kekebalan tubuh melalui stimulasi sel-sel tertentu di usus. Fuller (2002) menyatakan bahwa keseimbangan mikroba usus tercapai apabila mikroorganisme yang menguntungkan dapat menekan mikroorganisme yang merugikan. Selanjutnya dinyatakan bahwa prinsip kerja probiotik meliputi kompetisi untuk mendapatkan zat makanan, kompetisi mendapatkan tempat adhesi pada dinding usus, dan penghambatan secara langsung terhadap kehidupan mikroba yang dikalahkan, sedangkan menurut Budiansyah (2004), mekanisme kerja dari probiotik dapat dijelaskan sebagai berikut :

\section{Melekat atau Menempel dan Berkolo- nisasi dalam Saluran Pencernaan}

Kemampuan probiotik untuk bertahan hidup dalam saluran pencernaan dan menempel pada sel - sel usus merupakan tahap pertama untuk kolonisasi dan selanjutnya memodifikasi sistem kekebalan hewan inang. Kemampuan menempel yang kuat pada sel sel usus ini akan menyebabkan mikroba probiotik berkembang dengan baik dan mikroba patogen tereduksi dari sel-sel usus inang sehingga pertumbuhan dari mikroba patogen dapat terhambat.

\section{Kompetisi untuk Memperoleh Makanan dan Memproduksi Zat Antimikroba}

Mikroba probiotik menghambat organisme patogen dengan cara berkompetisi untuk mendapatkan sejumlah substrat bahan makanan untuk difermentasi. Substrat makanan tersebut diperlukan agar mikroba probiotik dapat berkembang dengan baik. Substrat bahan makanan yang mendukung perkembangan mikroba probiotik dalam saluran pencernaan disebut "prebiotik" (Patterson dan Burkholder, 2003). Prebiotik ini adalah terdiri dari bahan-bahan makanan yang pada umumnya banyak mengandung serat.

Sejumlah mikroba probiotik menghasilkan senyawa atau zat - zat yang diperlukan untuk membantu proses pencernaan substrat bahan makanan tertentu dalam saluran pencernaan yaitu enzim. Mikroba probiotik penghasil asam laktat dari spesies Lactobacillus, menghasilkan enzim selulase yang membantu proses pencernaan. Enzim ini mampu memecah serat kasar yang merupakan komponen yang sulit dicerna dalam saluran pencernaan unggas.

\section{Stimulasi Mukosa dan Peningkatkan Sistem Kekebalan Hewan Inang}

Kemampuan mikroba probiotik mengeluarkan toksin yang mereduksi atau menghambat perkembangan mikroba patogen dalam saluran pencernaan, merupakan suatu kondisi yang dapat meningkatkan kekebalan hewan inang. Toksin-toksin yang dihasilkan tersebut merupakan antibiotika bagi mikrobamikroba patogen, sehingga penyakit yang ditimbulkan oleh mikroba patogen tersebut berkurang atau dapat hilang atau sembuh dengan sendirinya. Hal ini dapat memberikan keuntungan terhadap kesehatan hewan inang sehingga tahan terhadap penyakit, dengan demikian pemberian probiotik pada ternak unggas diharapkan dapat memberikan manfaat terutama peningkatan penampilan produksi, yaitu kuantitas (produksi ternak dan daging yang tinggi) dan kualitas (kualitas telur dan daging yang baik dan higienis) sehingga kedepan diharapkan dapat menjadikan usaha peternakan unggas menjadi lebih ekonomis dan menguntungkan. Beberapa mikroba yang telah direkomendasikan oleh beberapa peneliti sebagai sumber probiotik disajikan pada Tabel 1.

Karakteristik probiotik yang baik adalah mengandung sel bakteri dan sel yeast hidup dalam jumlah yang besar, mengandung satu atau lebih strain spesifik dari host (induk semang) dan berspektrum luas, mempunyai kemampuan untuk berkolonisasi dalam saluran intestinal (resisten terhadap cairan lambung dan asam empedu) ketika dicerna, serta 
Tabel 1. Nama Dagang Probiotik dan Kandungan Mikroba

\begin{tabular}{ll}
\hline Produk & Jenis Mikroba \\
\hline Farlac & Streptococcus faecium \\
& SF-68 \\
FraSacc & Saccharomyces \\
& cerevisiae \\
Gist Brocadest & Unknown Yeast \\
Bio Plus & Bacillus subtilis, \\
& Bacillus lecheniformis \\
Toyoserin & Bacillus toyoi \\
Kem Pro & Saccharomyces \\
& cerevisiae \\
Lacto Sacc & Lactobacillus, \\
& Streptococcus, Yeast, \\
& Enzimes \\
Bio savor & Lactobacillus \\
& acidophillus, \\
Allac & L.plantarum \\
& Lactobacillus, \\
Sumber : Mulder et al., (1997)
\end{tabular}

cepat aktif, dan dapat disimpan dalam jangka waktu panjang dalam kondisi lapangan, serta dapat meningkatkan performans ternak (Fuller, 1992).

\section{PERAN PROBIOTIK BAGI TERNAK}

\section{Meningkatkan Kesehatan Ternak}

Pemberian probiotik dalam jumlah yang cukup dapat mempengaruhi komposisi dan ekosistem mikroflora pencernaannya. Kondisi ekosistem mikroflora dalam saluran pencernaan unggas mempengaruhi kinerja dan kesehatan ternak. Ketidakseimbangan mikroflora dalam saluran pencernaan karena terjadinya kolonisasi bakteri patogen atau mikroflora yang dapat mengganggu kinerja ternak, sebagai bahan alternatif untuk pemacu tumbuh. Cara kerja probiotik terutama melalui modifikasi populasi bakteri usus dan efektivitasnya tergantung atas status mikroba pada satu kelompok ternak dan pada individu ternak, dengan demikian, dapat dimengerti jika efek yang terjadi mempunyai variasi yang tinggi. Diketahui bahwa probiotik dapat meningkatkan kesehatan ternak. Hal ini diduga karena ada beberapa jenis mikroba di dalam probiotik yang menghasilkan asam-asam organik sehingga hal tersebut dapat menghambat pertumbuhan mikroba patogen di dalam saluran pencernaan.

Menurut Purwati et al. (2005), pemberian probiotik akan menciptakan keseimbangan mikroflora usus, karena adanya bakteri asam laktat dalam usus yang dapat menciptakan suasana asam sehingga menekan pertumbuhan bakteri patogen dalam usus halus. Probiotik dapat menjaga keseimbangan mikroba dalam saluran pencernaan yaitu melalui mekanisme competitive exclution yaitu kompetisi antara bakteri patogen dengan mikroorganisme probiotik sehingga bakteri patogen tidak dapat hidup dalam saluran pencernaan dan akan keluar bersama ekskreta (Murwani, 2008). Keseimbangan mikroba dalam saluran pencernaan terjadi apabila komposisinya terdiri atas $85 \%$ mikroba yang menuntungkan dan $15 \%$ mikroba patogen (Sjofjan, 2003).

\section{Meningkatkan Efisiensi Penggunaan Ransum}

Feed Pemberian probiotik starbio dengan level 3 dan $6 \mathrm{~g} / \mathrm{kg}$ pada pakan berbagai jenis itik lokal dapat menurunkan kadar trigliserida darah itik sebesar 46,3\%, namun belum dapat menurunkan kadar kolesterol darah itik (Wijaya et al., 2013). Interaksi antara level probiotik dan jenis itik lokal tidak menyebabkan perbedaan kondisi hematologis ditinjau dari jumlah eritrosit, kadar hemoglobin, dan hematokrit. Itik Tegal memiliki kadar hemoglobin darah lebih tinggi dibandingkan dengan itik Magelang dan itik Mojosari. Pemberian berbagai level probiotik pada berbagai jenis itik lokal tidak mengubah jumlah eritrosit, kadar hemoglobin, dan hematokrit (Ali et al., 2013). Pemberian probiotik $10^{-9}$ dan $2,5 \%$ tepung kunyit dalam ransum dapat mempertahankan $\mathrm{pH}$, meningkatkan warna, dan mengurangi aroma amis pada daging itik Pegagan (Sari et al., 2015). Itik Magelang mampu memberikan respon yang paling baik terhadap pemberian probiotik sebesar $6 \mathrm{~g} / \mathrm{kg}$ pakan dengan kadar HDL sebesar 27,87 mg/dl dan kadar LDL 
sebesar 129,70 mg/dl dibandingkan dengan itik Tegal dan Mojosari (Rosadi et al., 2013). Pemberian probiotik starbio dengan level 3 dan $6 \mathrm{~g} / \mathrm{kg}$ pada pakan berbagai jenis itik lokal dapat menurunkan kadar trigliserida darah itik sebesar 46,3\%, namun belum dapat menurunkan kadar kolesterol darah itik (Wijaya et al., 2013). Interaksi antara level probiotik dan jenis itik lokal tidak menyebabkan perbedaan kondisi hematologis ditinjau dari jumlah eritrosit, kadar hemoglobin, dan hematokrit. Itik Tegal memiliki kadar hemoglobin darah lebih tinggi dibandingkan dengan itik Magelang dan itik Mojosari. Pemberian berbagai level probiotik pada berbagai jenis itik lokal tidak mengubah jumlah eritrosit, kadar hemoglobin, dan hematokrit (Ali et al., 2013). Pemberian probiotik $10^{-9}$ dan $2,5 \%$ tepung kunyit dalam ransum dapat mempertahankan $\mathrm{pH}$, meningkatkan warna, dan mengurangi aroma amis pada daging itik Pegagan (Sari et al., 2015). Itik Magelang mampu memberikan respon yang paling baik terhadap pemberian probiotik sebesar $6 \mathrm{~g} / \mathrm{kg}$ pakan dengan kadar HDL sebesar 27,87 mg/dl dan kadar LDL sebesar $129,70 \mathrm{mg} / \mathrm{dl}$ dibandingkan dengan itik Tegal dan Mojosari (Rosadi et al., 2013). Convertion Ratio (FCR) merupakan salah satu indikator yang dapat memberikan gambaran tentang tingkat efisiensi penggunaan ransum. Semakin rendah FCR semakin tinggi efisiensi penggunaan ransum (Titus dan Frits, 1979). Pemberian probiotik pada unggas dapat mengefisienkan penggunaan pakan. Sesuai dengan pendapat Zainuddin et al. (1994), penggunaan probiotik starbio dalam pakan ternak mampu meningkatkan efisiensi pakan melalui mekanisme kerja starbio yang mampu mencerna lemak, serat kasar, dan protein dalam pakan menjadi bahan yang mudah diserap. Pernyataan ini juga dipertegas oleh Samadi (2007) menyatakan pemberian probiotik dapat menjaga keseimbangan komposisi mikroorganisme dalam sistem pencernaan ternak, berakibat meningkatnya daya cerna bahan pakan dan menjaga kesehatan ternak. bakteri-bakteri probiotik berada pada mukosa pencernaan dan dapat mengubah komposisi dari bakteri yang terdapat dalam saluran pencernaan, karena itu, konversi pakan itik yang diberi perlakuan probiotik menjadi lebih baik jika dibandingkan dengan itik yang tidak diberi probiotik.

Widyastuti dan Soarianawati (1999) menyatakan probiotik mampu mencegah tumbuhnya bakteri atau organisme yang merugikan bagi induk semangnya, dan dapat meningkatkan kecernaan dan penyerapan nutrien pakan karena mampu merangsang peristaltis yaitu gerakan usus karena adanya kompetisi antara mikroorganisme probiotik dengan bakteri patogen guna menempel pada epithel usus sehingga secara simultan akan membantu aktivitas dan perkembangan usus. Probiotik dalam ransum dapat meningkatkan aktivitas enzimatis dan meningkatkan aktivitas pencernaan, akibatnya zat nutrisi seperti lemak, protein, dan karbohidrat yang biasanya banyak terbuang dalam faeces akan menjadi berkurang (Jin et al., 1997).

\section{PENGGUNAAN PROBIOTIK PADA ITIK}

Target utama dari penggunaan probiotik yaitu: (i) peningkatan ketahanan inang terhadap patogen eksogenus pencernaan; (ii) mengontrol penyakit dimana komponen mikroflora pencernaan telah diimplikasi dalam aeteologi; (iii) menurunkan keracunan metabolisme mikrobial dalam pencernaan; dan (iv) mengatur sistim imunitas inang. Secara keseluruhan, tujuan dari strategi ini yaitu meningkatkan pertumbuhan bakteri yang dapat bersaing dengan, atau antagonis terhadap bakteri patogen. Produk probiotik yang diberikan biasanya distandarisasi berdasarkan perkiraan jumlah kultur dapat hidup (viable), jadi kemampuan strain untuk mencapai populasi sel yang tinggi merupakan hal yang sangat penting. Konsentrasi yang umum dianggap dapat berguna yaitu kira-kira $10^{7} \mathrm{sel} / \mathrm{ml}$ pada saat dikonsumsi (Gomes dan Malcata, 1999).

Riswandi (2012) melaporkan bahwa penambahan Starbio dan EM-4 sebanyak 0,1\% EM-4 (1 ml EM-4/liter air minum) yang dicampurkan ke dalam air minum ditambah starbio sebanyak $0,2 \%$ (2 $\mathrm{g} / \mathrm{kg}$ ransum) dapat 
menurunkan konsumsi ransum 19,72\% tetapi relatif sama terhadap konsumsi air minum, pertambahan bobot badan dan konversi ransum itik lokal dibanding dengan kontrol. Agustina et al. (2013) menyatakan pemberian probiotik sampai level $6 \mathrm{~g} / \mathrm{kg}$ pakan dan jenis itik tidak meningkatkan pertumbuhan dan konsumsi pakan. Menurut Haryati (2011), probiotik dan prebiotik adalah bahan yang dapat digunakan untuk menggantikan penggunaan antibiotik yang dapat meningkatkan kinerja ternak. Penggunaan probiotik dan prebiotik sudah banyak diterapkan di luar negeri karena memberikan hasil yang positif, tetapi di Indonesia penelitian dan penggunaan kedua bahan ini masih belum banyak dilakukan. Berbagai sumber kedua bahan tersebut belum diekplorasi secara optimal agar dapat dimanfaatkan sehingga memberikan dampak yang positif terhadap usaha peternakan. Pemberian probiotik Probio_FM melalui air minum $1 \%$ ditambah dalam pakan $1 \%$ dapat meningkatkan status kesehatan ternak itik. Terliahat dari penurunan $\mathrm{pH} 10 \%$, penurunan total koloni E.coli $19,91 \%$ dan peningkatan total koloni Lactobacillus 8,30 \% di usus halus itik jantan periode pertumbuhan (Manim et al., 2014). Penambahan starbio pada pakan dan EM-4 pada air minum dapat meningkatkan pertumbuhan dan efisiensi penggunaan ransum, tetapi tidak berpengaruh terhadap konsumsi pakan (Laksmiwati, 2006).

Djouvinov et al. (2005) menyatakan pemberian pakan probiotik lactina pada itik mule meningkatkan konsentrasi lactobacillus $82,89 \%$, menurunkan konsentrasi salmonella $54,54 \%$ dan E. coli $67,47 \%$ dalam sekum. Selain itu, peningkatan bobot badan, pengurangan $4 \%$ mrasio konversi ransum dan tingkat kematian yang lebih rendah, hemoglobin darah, total protein dan total konsentrasi kolesterol tidak signifikan dipengaruhi oleh probiotik. Pemberian probiotik starbio dengan level 3 dan $6 \mathrm{~g} / \mathrm{kg}$ pada pakan berbagai jenis itik lokal dapat menurunkan kadar trigliserida darah itik sebesar 46,3\%, namun belum dapat menurunkan kadar kolesterol darah itik (Wijaya et al., 2013). Interaksi antara level probiotik dan jenis itik lokal tidak menyebabkan perbedaan kondisi hematologis ditinjau dari jumlah eritrosit, kadar hemoglobin, dan hematokrit. Itik Tegal memiliki kadar hemoglobin darah lebih tinggi dibandingkan dengan itik Magelang dan itik Mojosari. Pemberian berbagai level probiotik pada berbagai jenis itik lokal tidak mengubah jumlah eritrosit, kadar hemoglobin, dan hematokrit (Ali et al., 2013). Pemberian probiotik $10^{-9}$ dan $2,5 \%$ tepung kunyit dalam ransum dapat mempertahankan $\mathrm{pH}$, meningkatkan warna, dan mengurangi aroma amis pada daging itik Pegagan (Sari et al., 2015). Itik Magelang mampu memberikan respon yang paling baik terhadap pemberian probiotik sebesar $6 \mathrm{~g} / \mathrm{kg}$ pakan dengan kadar HDL sebesar 27,87 mg/dl dan kadar LDL sebesar 129,70 mg/dl dibandingkan dengan itik Tegal dan Mojosari (Rosadi et al., 2013).

\section{KESIMPULAN}

Dari hasil bacaan di atas dapat disimpulkan bahwa aplikasi probiotik untuk ternak itik dapat melalui air minum, pakan atau gabungan keduanya, konsentrasi pemberian probiotik tersebut minimal $10^{7}$ sel/ml. Probiotik memberikan pengaruh yang baik terhadap itik seperti meningkatkan konsentrasi Lactobacillus 8,30 \%, menurunkan konsentrasi 19,91 \%, menurunkan $\mathrm{pH}$ di dalam usus halus, menurunkan konsumsi ransum 19,72 \% dan menurunkan rasio konversi ransum sampai $4 \%$.

\section{DAFTAR PUSTAKA}

Agustina, D., Iriyanti, N., dan Mugiyono. S. 2013. Pertumbuhan dan konsumsi pakan pada berbagai jenis itik lokal betina yang pakannya di suplementasi probiotik. Ilmiah peternakan 1(2): 691 $-698$.

Ali, S.A., Ismoyowati dan I. Diana. 2013. Jumlah eritrosit, kadar hemoglobin dan hematokrit pada berbagai jenis itik lokal terhadap penambahan probiotik 
dalam ransum. Jurnal Ilmiah peternakan. 1(3): 1001-1013.

Bilgili, S.F. 1995. Competitive Exclusion: The Basics. Broiler Industry. 18 p.

Budiansyah, A. 2004. Pemanfaatan Probiotik Dalam Meningkatkan Penampilan Produksi Ternak Unggas. Prog Pascasarjana Intitut Pertanian Bogor. Bogor.

Direktorat Jendral Peternakan 2012. Populasi Itik Menurut Provinsi. Jakarta.

Djouvinov, M., Boicheva, S., Simeonova,T and Vlaikova, T. 2005. Effect of feeding Lactina probiotic on performance, some blood parameters and caecal microflora of mule ducklings. Journal of Sciences, Vol. 3, No. 2, pp 22-28.

[FAO] Food and Agriculture Organizatiom. 2004. Small scale poulty and health. Village Poulty Consultant. Waimana,New Zealand. Pp:1-5.

Fuller, R. 1989. Probiotic in man and animals. J. Appl. Bacteriol. 66: 365 - 378.

Fuller, R. 1992. History and Development of Probiotics. In Probiotics the Scientific basis. Edited by Fuller. Chapman and hall. London, New York, Tokyo, Melbourne, Madras. Pp. 1 - 7.

Fuller, R., 2002, Probiotic- What they are and what they do. http://D:/Probiotic. What they and what do, html.

Gaggia, F., P. Mattarelli and B. Biavati. 2010. Probiotic and prebiotics in animal feeding for safe food production. Intl. J. Food Microbiol. 14: 515 - 528.

Gomes, A.M.P. and F.X. Malcata. 1999. Bifidobacterium spp. and Lactobacillus acidophilus: Biological, biochemical, technological and therapeutical properties relevant for use as probiotics. Trends Food. Sci. Technol. 10: 139 - 157 .

Gusils, C., A.P.Chaia, S. Gonzalez and G. Oliver. 1999. Lactobacilli isolated from chicken intestines: Potential use as probiotics. J. Food. Protect. 2(3): $252-256$.

Haryati, T. 2011. Probiotik dan prebiotik Sebagai pakan imbuhan nonruminansia. Balai Penelitian Ternak, PO Box 221, Bogor.

Hidayat, M. N. 2010. Perlekatan Mikroba Probiotik Pada Saluran Pencernaan ternak Unggas. http:// www. lambung satu.blogspot2010.com. (10 Januari 2012).

Isshiki, Y. 1979. Effect of lactobacili in the diet on the concentration of nitrogenus chikens. Japanese Poultry Sci. 16:254258.

Jin, L.Z., Y.W. Ho, N. Abdullah and S. Jalaludin. 1997. Probiotics in Poultry : Modes of Action. Worlds Poultry Sci. J. 53 (4) : $351-368$.

Klaim. 2006. The Online Encyclopaedia. Wikipedia. probiotik juga ikut berperan dalam meningkatkan kekebalan tubuh.

Kompiang IP. 2009. Pemanfaatan mikroorganisme sebagai probiotik untuk meningkatkan produksi ternak unggas di Indonesia. Pengembangan Inovasi Pertanian 2:177-191.

Laksmiwati, M. 2006. Pengaruh Pemberian Starbio Dan Effective Microorganism4 (Em-4) Sebagai Probiotik Terhadap Penampilan Itik Jantan Umur $0-8$ Minggu Jurusan Produksi Ternak, 
Fakultas Peternakan, Universitas Udayana, Denpasar.

Manim, F., Hendalia, E., Yatno dan Rahayu, P. 2014. Dampak pemberian probiotik Probio_FM terhadap status kesehatan ternak itik kerinci. Jurnal ilmu ternak. Volume 1 Nomor 2,7-11.

Mulder, R.W.A.W., R. Havenaar, and J.H.J. Huis in't Veld. 1997. Intervention strategies : the use of probiotics and competitive exclution microfloras against contamination with pathogens in pigs and poultry. Dalam Probiotics 2, Application and practical aspects. Edited by Fuller. Chapman \& Hall, London-Weinhiem-New York-TokyoMelbourne-Madras.

Nisbet, D.J., D.E. Corrier and J.R. Deloach. 1993. Effect of mixed cecal microflora maintained in continuous culture, and dietary lactose on Salmonella typhimurium colonization in broiler chicks. Avian Dis. 37: 528 - 535.

Nisbet, D.J., D.E. Corrier, S. Ricke, M.E. Hume, J.A. Byrd, and J.R. Deloach. 1996. Maintenance of the biological efficacy in chicks of a cecal competitiveexclusion culture against Salmonella by continuous flow fermentation. J. Food Prot. 59: 1279 1283.

Nurmi, E., L. Nuotio and C. Schncitz. 1992. The competitive exclusion concept: Development and future. Int. J. Food Microbiol. 15: 237 - 240.

Pal, A., L. Ray and P. Chattophadhyay. 2006. Purification and immobilization of an Aspergillus terreus xylanase: Use of continuous fluidized column reactor. Ind. J. Biotechnol. 5: 163 - 168.
Patterson, J.A dan K.M. Burkholder, 2003. Application of prebiotics and probiotics in poultry production. Poultry Science. 82: 627-631.

Prasetyo H L, Ketaren P P, Setioko R A, Supayanto A, Juuwarini E, Susanti T, Supiana S. 2010. Panduan budidaya dan usaha ternak itik. Balai penelitian ternak, Ciawi Bogor.

Purwati, E., S. Syukur, dan Z. Hidayat. 2005. Lactobacillus, Isolasi dari Biovicophitomega sebagai probiotik. Lembaga Ilmu Pengetahuan Indonesia, Jakarta.

Ray, R. 1996. Fundamental Food Microbiology. CRC Press. Boca Raton Inc. New York.

Riswandi., Sandi, S dan Yosi, S. 2012. Kombinasi Pemberian Starbio dan EM-4 Melalui Pakan dan Air Minum terhadap Performan ltik Lokal Umur 16 Minggu. Jurnal Peternakan Sriwijaya (JPS). Volume 1 Nomor 1.

Rosadi, I., Ismoyowati dan N. Iriyanti. 2013. Kadar HDL (High Density Lipoprotein) dan 1DL (Low Density Lipoprotein) Darah pada Berbagai Itik Lokal Betina yang Pakannya Disuplementasi dengan Probiotik. Jurnal Ilmiah Peternakan 1(2): 597 605 .

Sari, M.L., F.N.L. Lubis dan K. Dewi. 2015. Pengaruh Pemberian Probiotik dan Tepung Kunyit (Curcuma Domestica Val) Dalam Ransum terhadap $\mathrm{pH}$, Warna, dan Aroma Daging Itik Pegagan. Jurnal Peternakan Sriwijaya. Volume. 4, No. 1. pp. 47-53 ISSN $2303-109347$.

Saarela, M., G. Mogensen, R. Fonde, J. Matto and T.M. Sandholm. 2000. Probiotic bacteria: Safety, functional and 
technological properties. J. Biotechnol. 84(2000): 197 - 215.

Salminen, S., E. Isolauri and E. Salminen. 1996. Clinical uses of probiotics for stabilizing the gut mucosal barrier: Successful strains and future challenges. Antonie van Leeuwenhoek 70: $347-358$.

Samadi, 2007. Probiotik Pengganti Antibiotik dalam Pakan Ternak.

Simon, O. 2005. Micro-organism as feed additives-probiotics Advances in Pork Production 16: 161-167.

Sjofjan, O. 2003. Kajian Probiotik (Aspergillus niger dan Bacillus spp) sebagai Imbuhan Ransum dan Implikasi Efeknya terhadap Mikroflora Usus serta Penampilan Produksi Ayam Petelur. Disertasi. Universitas Padjajaran, Bandung.

Soeharsono. 1998. Probiotik sebagai pengganti antibiotik dalam bidang peternakan. Seminar Fakultas Peternakan. Universitas Padjadjaran. Bandung.

Stark, B.A. and J.M. Wilkinson. 1989. Probiotics: Theory and application. Chalcombe Publications Berks, England.
Steer, T., H. Carpenter, K. Tuohy, G.R. Gibson and T.E. Steer. 2000. Perspectives on the role of the human gut microbiota and its modulation by pro- and prebiotics. Nutr. Res. Rev. 13: $229-254$.

Titus, H.W. and J.C. Frits. 1979. The Scientifics Feeding of Chickens $9^{\text {th }} \mathrm{Ed}$. The Interstate Priters and Publisher Inc. Danvil, Illinois.

Widyastuti dan Soarianawati (1999.

Widyastuti, Y. dan E. Soarianawati. 1999. Karakter bakteri asam laktat Enterococcus sp. yang diisolasi dari saluran pencernaan ternak. J. mikrobiologi Indonesia. 4 (2): 50-53.

Wijaya, G.V., Ismoyowati dan S.M. Dadang. 2013. Kajian Kadar Kolesterol dan Trigliserida Darah Berbagai Jenis Itik Lokal yang Pakannya Disuplementasi dengan Probiotik. Jurnal Ilmiah Peternakan. 1(2): $661-668$.

Zainuddin, D., D.K. Diwyanto dan Suharto. 1994 Penggunaan Probiotik Starbio (Starter Mikroba) Dalam Ransum Ayam Pedaging Terhadap Produktivitas, Nilai Ekonomis (IOFC) dan Kadar Amonia Lingkungan Kandang. Balai Penelitian Ternak, Ciawi. Bogor. 